\title{
Multiple mechanisms underlying the cytoprotective effect of afobazole
}

\author{
Mikhail V. Voronin, Ilya A. Kadnikov, Sergey B. Seredenin \\ Pharmacogenetics, FSBI Zakusov Institute Of Pharmacology, Russia
}

Background. Anxiolytic afobazole (5-Ethoxy-2-[2-(morpholino)-ethylthio] benzimidazole dihidrochloride) has ligand properties towards Sigma-1 chaperone ( $\sigma 1$ receptor, Sigma1R; $\left[{ }^{3} \mathrm{H}\right](+)$-pentazocine IC50 $=7.1 \mathrm{E}-6 \mathrm{M}$ ) and the melatonin binding site $\left(\mathrm{MT}_{3}\right.$ receptor; $\left.{ }^{125} \mathrm{I}\right] 2$-iodomelatonin $\left.\mathrm{IC} 50=9.9 \mathrm{E}-7 \mathrm{M}\right)$ of N-Ribosyldihydronicotinamide: Quinone Reductase 2 (NQO2) in ligand binding assay. Further studies revealed its cytoprotective and neuroprotective action in various experimental models. Review analysis of scientific publications and our own findings suggest possible dependence of afobazole cytoprotective effects on both Sigma1R and NQO2. Importantly, the afobazole main metabolite M-11 (2-[2-(3-oxomorpholin-4-il)-ethylthio]-5-ethoxybenzimidazole hydrochloride) has significant affinity only to $\mathrm{MT}_{3}$ receptor $\left(\left[{ }^{125} \mathrm{I}\right] 2\right.$-iodomelatonin $\left.\mathrm{IC} 50=4.0 \mathrm{E}-7 \mathrm{M}\right)$. The combination of afobazole, its metabolite M-11 and Sigma1R selective ligands became a very convenient tool to test this hypothesis. The aim of this study was to investigate the contribution of Sigma1R and NQO2 in afobazole cytoprotective effects.

Methods. We utilized SCGE-assay (comet assay) to evaluate DNA damage in mouse bone marrow cells exposed to menadione as a marker of oxidative stress in vitro.

Results. Afobazole distinctly decreases menadione induced DNA damage. Preincubation of cell suspension with Sigma1R selective antagonist BD-1047 at $1 \mu \mathrm{M}$ or $10 \mu \mathrm{M}$ leads to significant decrease of afobazole cytoprotective action. Meanwhile incubation of cell suspension only with BD-1047 at both concentrations has no impact on menadione induced DNA damage. Metabolite M-11 at $50 \mu \mathrm{M}$ decreases menadione induced DNA damage indicating less cytoprotective potential than afobazole. Pre-incubation of cell suspension with BD-1047 prior adding M-11 at $50 \mu \mathrm{M}$ concentration has no impact on its cytoprotective effect due to lack of M-11 ligand properties towards Sigma1R. Next, the effects of afobazole were compared with effects of selective Sigma1R agonist PRE-084. PRE-084 at $1 \mu \mathrm{M}$ and $10 \mu \mathrm{M}$ also decreased DNA damage but cytoprotective effect of PRE-084 was much weaker as compared to afobazole.

Conclusion. Our in vitro experiments on the model of menadione genotoxicity demonstrate the dependence of afobazole cytoprotective effect on melatonin binding site of NQO2 and Sigma1R. 